Article Review

\title{
Vaksinasi Measles, Mumps, dan Rubella (MMR) sebagai Prophylaxis Terhadap COVID-19
}

\author{
Sajuni ${ }^{1 *}$ \\ ${ }^{1}$ Fakultas Kedokteran, Universitas Surabaya, Surabaya-Indonesia \\ * corresponding author:dr.sajuni@gmail.com
}

\begin{abstract}
COVID-19 is an infection caused by SARS-CoV-2 and has been declared a pandemic by WHO. At present, there is no therapy or vaccine available for handling COVID-19. Data obtained in China, Italy, and South Korea show fewer children under 10 years of age are infected with COVID-19, and even if they have an infection they generally experience mild symptoms even without symptoms. Children get routine vaccinations and various infections. This seems to train the immune system of children so that it is more immune to COVID-19. MMR vaccination demonstrates partial preventive protection against COVID-19. This is due to several previous studies that the measles vaccine protects against pathogens other than measles and also because of the similarity between the protein S in SARS-CoV-2 with protein Fin Measles virus (measles) and protein E in Rubella virus (German measles). Prophylaxis is a way to prevent disease. This review will discuss the possibility of giving MMR vaccination as a protection against COVID-19.
\end{abstract}

Keywords: SARS-CoV-2, COVID-19, prophylaxis, MMR

\begin{abstract}
Abstrak-COVID-19 merupakan infeksi yang dikarenakan SARS-CoV-2 dan telah dinyatakan sebagai pandemi oleh WHO. Saat ini belum didapatkan terapi maupun vaksin dalam menangani COVID-19. Data yang didapat di negara China, Itali dan Korea selatan menunjukkan a nak-a nak usia di bawah 10 tahun lebih sedikit yang terinfeksi COVID-19, dan kalaupun mengalami infeksi umumnya mengalami gejala ringan bahkan tanpa gejala. Anak-anak mendapatkan rutin vaksinasi dan berbagai infeksi. Hal ini nampaknya melatih sistem imun a nak-a nak sehingga lebih kebal terhadap COVID-19. Vaksinasi MMR menunjukkan perlindungan pencegahan parsial terhadap COVID-19. Hal ini dikarenakan beberapa penelitian sebelumnya bahwa vaksin campak memberikan perlindungan terhadap pathogen selain campak dan juga karena adanya kesamaan antara protein S SARS-CoV-2 dengan protein F pada virus Measles (campak) dan protein E pada virus Rubella (campak jerman). Profilaksis merupakan cara untuk mencegah penyakit. Review ini akan membahas mengenai kemungkinan pemberian vaksinasi MMR sebagai perlindungan terhadap COVID-19.
\end{abstract}

Kata kunci: SARS-CoV-2, COVID-19, profilaksis, MMR

\section{PENDAHULUAN}

Coronavirus disease 2019 (COVID-19) dikarenakan infeksi virus Severe Acute Respiratory Syndrome Coronavirus-2 (SARS-CoV-2) merupakan krisis masalah kesehatan terbesar dunia saat ini [1]. COVID-19 bermula dari daerah Wuhan, China dan telah dinyatakan menjadi pandemi pada Maret 2020 oleh WHO [2]. Pada saat artikel ini ditulis telah terdapat total 8.756 .688 kasus dengan kematian sebesar 462.501 di seluruh dunia. Di Indonesia telah terdapat 43.803 kasus dan 2.373 kematian dikarenakan COVID-19 [3].

Data pasien yang terinfeksi COVID-19 di negara China, Itali, dan Korea Selatan menunjukkan bahwa anak anak usia di bawah 10 tahun lebih sedikit yang terinfeksi dan jika terjangkit pun ringan [5]. Data di Indonesia per tanggal 23 Mei 2020 menurut Ikatan Dokter Anak Indonesia terdapat kurang dari 0.1\% anak yang terinfeksi COVID-19 [6]. Namun, didapatkan beberapa penemuan yang menunjukkan bahwa bayi (usia di bawah 1 tahun) rentan terinfeksi COVID-19 dan jika terinfeksi umumnya lebih berat [7]. Hal ini mungkin dikarenakan anak-anak sampai usia 6 tahun mendapatkan berbagai vaksinasi [8]. Vaksin-vaksin tersebut membentuk kekebalan melindungi sel paru terhadap masuknya SARS-CoV-2 [9].

Reaksi silang antara pemberian vaksinasi dan genus virus lainnya telah didapatkan ketika vaksin campak meningkatkan kadar serum antibodi terhadap HIV. Kebanyakan vaksin untuk virus (mati atau inaktivasi) dapat menstimulus sel Th1 (CD4+) untuk mengeluarkan berbagai tipe sitokin antara lain interferon gamma, interleukin-2 (IL-2), dan IL-12. IL-12 mengakibatkan pematangan sel limfosit T CD8+ dan meningkatkan kemampuan sel NK dalam mengenal dan menghancurkan sel yang terinfeksi virus [10].

Pasien COVID-19 mengalami kondisi limfopenia dan penurunan jumlah sel limfosit T CD8+ [11]. Vaksin MMR meningkatkan imunitas humoral terhadap COVID-19 [12]. Profilaksis

(c) (i) () http://journal.ubaya.ac.id/index.php/kesdok l e-ISSN: 2715-6419


merupakan cara untuk mencegah penyakit dan merupakan strategi dalam menangani COVID19, karena dapat mencegah penyebaran SARS-CoV-2 dan mencegah terjadinya COVID-19 [13]. Review ini membahas kemungkinan vaksinasi MMR sebagai profilaksis terhadap COVID-19.

\section{STRUKTUR SARS-COV-2}

Coronavirus merupakan virus yang memiliki envelope dengan genom RNA positif (26$32 \mathrm{~kb})$ dan mengalami replikasi di sitoplasma sel yang terinfeksi. Terdapat empat genus coronavirus $(\alpha, \beta, \gamma, \delta)$. SARS-CoV-2 termasuk $\beta$ coronavirus [14]. Partikel virus terdiri atas empat protein struktural mayor, yaitu: nukleoprotein $(\mathrm{N})$, protein envelope kecil $(\mathrm{E})$, membrane protein (M), dan protein Spike (S). Masuknya coronavirus ke dalam sel dimediasi oleh spike transmembrane glikoprotein S. Protein S ini mengandung determinan antigenic dan merupakan target untuk menetralisir antibodi [15]. Pertahanan utama adalah dengan menghambat perlekatan protein S dengan reseptor host yaitu ACE2 (angiotensin-converting enzyme 2) [16]. Protein S terdiri atas dua fungsional unit yaitu S1 dan S2 [17].

\section{Coronavirus dan Paramyxovirus}

Paramyxovirus merupakan virus yang termasuk dalam keluarga Paramyxoviridae. Virus ini memiliki envelope, satu untai RNA negative. Lipoprotein envelope mengandung dua spike glikoprotein yaitu Hemagglutinin neuraminidase (HN) dan Fusion factor (F) [18]. Paramyxoviridae memiliki dua subfamily yaitu Paramyxovirinae dan Pneumovirinae. Campak dan juga Mumps (gondongan) termasuk dalam subfamily Paramyxovirinae (19). Didapatkan persamaan 30 asam amino antara glikoprotein SARS-CoV-2 dengan glikoprotein F1 virus Measles, juga pada glikoprotein E1 virus Rubella. Kesamaan ini tampaknya berperan sebagai epitope yang terlibat dalam produksi antibody; hal ini diketahui menggunakan alat prediksi antibodi secara online [20].

\section{IMUNISASI DAN VAKSINASI}

Imunisasi adalah proses menginduksi imunitas secara buatan baik dengan vaksinasi (imunisasi aktif) maupun dengan pemberian antibodi (imunisasi pasif). Imunisasi aktif menstimulasi sistem imun untuk membentuk antibodi dan respon imun seluler yang melawan agen penginfesi, sedangkan imunisasi pasif menyediakan proteksi sementara melalui pemberian antibodi yang diproduksi secara eksogen maupun transmisi transplasenta dari ibu ke janin.

Vaksinasi, yang merupakan imunisasi aktif, ialah suatu tindakan yang dengan sengaja memberikan paparan antigen dari suatu patogen yang akan menstimulasi sistem imun dan menimbul kan kekebalan sehingga nantinya anak yang telah mendapatkan vaksinasi tidak akan sakit jika terpajan oleh antigen serupa. Antigen yang diberikan dalam vaksinasi dibuat sedemikian rupa sehingga tidak menimbulkan sakit, namun dapat memproduksi limfosit yang peka, antibodi, maupun sel memori.

Imunisasi yang rutin diberikan pada anak adalah imunisasi aktif yaitu vaksinasi (21). Anak-anak memiliki respons imun awal yang kuat dan mengontrol masuknya SARS-CoV-2 pada awal infeksi, hal ini dikarenakan imunitas yang terlatih (dikarenakan vaksinasi virus hidup dan seringnya infeksi virus pada masa anak) [7].

\section{Mekanisme Protektif Imunologis Pada Anak}

Imunitas pada anak menjadi terlatih setelah mendapat berbagai stimulasi antigen (infeksi maupun vaksinasi) dan mengakibatkan perubahan imunitas alami menjadi imunitas adaptif [22]. Negara dengan pemberian vaksinasi rutin BCG menunjukkan rendahnya angka morbiditas dan mortalitas COVID-19 [23]. Pada dewasa yang dilakukan pemberian vaksinasi BCG didapatkan peningkatan kemampuan reseptor monosit mengenali pathogen dan peningkatan Th1 dan Th17 terhadap stimulasi non-mikobakterial sampai 1 tahun setelah vaksinasi (24]. BCG saat ini dipertimbangkan sebagai salah satu cara untuk meningkatkan 
imunitas pada populasi berisiko mengalami COVID-19 yang parah seperti orang tua dan petugas kesehatan [7].

\section{Vaksinasi MMR (Measles, Mumps, Rubella)}

Vaksinasi akan meningkatkan respons imun spesifik terhadap pathogen spesifik melalui terbentuknya antibodi yang akan berikatan dan menetralisir pathogen tertentu. Namun vaksin yang mengandung virus Measles (campak) memiliki kemampuan menaikkan sistem imun melawan pathogen selain virus campak.

\section{COVID-19 dan Vaksin MMR}

Vaksin MMR melindungi secara parsial terhadap COVID-19. Vaksin ini menginduksi sistem imun melawan infeksi, mengurangi kemampuan virus dalam mengakibatkan gangguan fatal dan mengontrol infeksi menuju kesembuhan. Terdapat dua mekanisme ketika vaksin MMR melindungi secara parsial terhadap COVID-19. Pertama adalah vaksin MMR meningkatkan kemampuan sistem imun melawan pathogen selain terhadap virus measles, mumps dan rubella. Kedua adalah adanya kesamaan struktur pada protein S SARS-CoV-2 dengan protein $\mathrm{F}$ virus Measles dan protein E virus Rubella, yang mengakibatkan reaksi silang dan antibodi terhadap SARS-CoV-2 dan mengakibatkan perlindungan terhadap COVID-19 [18, 19].

\section{PENUTUP}

Data mengenai perlindungan parsial vaksinasi MMR terhadap COVID-19 pada pasien di Indonesia belum ada, maka perlu dilakukan penelitian lanjutan mengenai efek perlindungan vaksinasi MMR terhadap COVID-19 pada masyarakat Indonesia. Juga tidak menutup kemungkinan dilakukan pula penelitian lanjutan mengenai efek berbagai vaksin lainnya (terutama vaksin hidup terhadap COVID-19).

\section{PUSTAKA ACUAN}

1. Jin Y, Yang H, Ji W, et al. Virology, Epidemiology, Pathogenesis, and Control of COVID19. Viruses. 2020;12(4):372. Published 2020 Mar 27. doi:10.3390/v12040372.

2. Liu J, Liao X, Qian S, Yuan J, Wang F, Liu Y, et al. Community Transmission of Severe Acute Respiratory Syndrome Coronavirus 2, Shenzhen, China, 2020. Emerg Infect Dis J (Internet) 2020;26(6).

3. WorldmeterCOVID- 19 Coronavirus Pandemic. https://www.worldometers.info/coronavirus/?utm_campaign=homeAdvegas1?, diunduh tanggal 20 Juni 2020.

4. Worldmeter COVID-19 Coronavirus Pandemic. https://www.worldometers.info/coronavirus/country/indonesia/, diunduh tanggal 20 Juni 2020.

5. Carrozzi G, Sampaolo L, Bolognesi L, Bertozzi N, Ferrante G, Minardi V, et al. Epidemic COVID-19. 2020.

6. https://www.kompas.com/tren/read/2020/05/23/162900365/viral-idai-ungkap-datakasus-covid-19-pada-anak-ini-penjelasannya?page=all, diunduh tanggal $20 \mathrm{Juni} 2020$.

7. Dhochak N, singhal T, Kabra SK, Lodha R. Pathophysiology of COVID-19: Why Children Fare Better Than Adults? Indian J Pediatrics. 2020.

8. Steinglass R. Routine immunization: an essential but wobbly platform. Glob Heal Sci Pract. 2013;1(3):295-301.

9. Salman s, Salem ML. Routine childhood immunization may protect against COVID-19. Medical Hypotheses. 2020.

10. Baskar PV, Collins GD, Dorsey-Cooper BA, Pyle RS, Nagel JE, Dwyer D, et al. serum antibodies to HIV-1 are produced post-measles virus infection: evidence for crossreactivity with HLA. Clin Exp Immunol. 1998. 
11. Bermejo-Martin JF, Almansa r, Menendez R, Mendez r, Kelvin DJ, Torres A. Lymphopenic community-acquired pneumonia as signature of severe COVID-19infection. The Journal of Infection. England; 2020.

12. Sidiq KR, Sabir DK, Ali SM dan Kodzius R. Does Early Childhood Vaccination Protect Against COVID-19? Front. Mol. Biosci. 7:120. 2020.

13. Sallard E, Lescure FX, Burdet C, Guedj J, Yazdanpanah Y, Smadja NP. Repurposed prophylaxis strategies for COVID-19: a review. 2020.

14. Li X, Geng M, Peng Y, Meng L, Lu S. Molecular Immune pathogenesis and diagnosis of COVID-19. Journal of Pharmaceutical Analysis. 2020.

15. Burkard, c. et al. Coronavirus cell entry occurs through the endo-/lysosomal pathway in a proteolysis-dependent manner. PLoS Pathog. 2014.

16. de Wit E, van Doremalen N, Falzarano D, et al. SARS and MERS: recent insights into emerging coronaviruses. Nat. Rev. Microbiol., 2016, 14: 523-534.

17. Spiga O, Bernini A, clutti A, Chiellini s, Menciassi N, Finetti F, Causarano V, Anselmi F, Prischi F dan Niccolai. Molecular modelling of S1 and S2 subunits of SARS coronavirus spike glycoprotein. Biochem. Biophys. Res. Commun. 2003, 310:78.

18. Saad ME, Elsalamony RA. Measles vaccines may provide partial protection against COVID-19. Int. J Cancer \& Biomedical Research. Vol. 5(1): 14-19. 2020.

19. Walls AC, Tortorici AM, Bosch B, Frenz B, Rottier PJM, DiMaio F, Rey FA dan Veesler D. Cryo-electron microscopy structure of a coronavirus spike glycoprotein trimer. Nature volume, 531:114-7. 2016.

20. Larsen JEP, Lund O, dan Nielsen M. Improved method for lineal B-cell. Epitopes. Immun Res. 2:2. 2006.

21. Hamborsky J, Kroger A, Wolfe C. Epidemiology and Prevention of Vaccine-Preventable Diseases $13^{\text {th }}$ Edition. CDC. 2015.

22. Netea MG, Dominguez J, Barreiro LB, et al. Defining trained immunity and its role in health and disease. Nat Rev Immunol. 2020.

23. Miller A, Reandelar MJ, Fasciglione K, roumenova V, Li Y, Otazu GH. Correlation between universal BCG vaccination policy and reduced morbidity and mortality for COVID-19: An epidemiological study. MedRxiv. 2020.

24. Kleinnijenbuis J, Quintin J, Preijers F, et al. Long-lasting effects of BCG vaccination on both heterologuous Th1/Th17 responses and innate trained immunity. J innate Immun. 2014. 